\title{
Bulletin of Animal Science
}

ISSN-0126-4400/E-ISSN-2407-876X

Accredited: $36 \mathrm{a} / \mathrm{E} / \mathrm{KPT} / 2016$

http://buletinpeternakan.fapet.ugm.ac.id/

Doi: 10.21059/buletinpeternak.v43i4.43256

\section{Estimation of Repeatability Value of Weaning Weight and Most Probable Producing Ability (MPPA) of Saburai Doe in Tanggamus Regency}

\author{
Kusuma Adhianto*, Tri Isngatirah, Sulastri, and Muhammad Dima Iqbal Hamdani \\ Department of Animal Husbandry, Faculty of Agriculture, University of Lampung, Bandar Lampung, 35145, Indonesia
}

Article history

Submitted: 1 February 2019

Accepted: 18 November 2019

* Corresponding author:

Telp. +62 81227972696

E-mail:

kusuma.adhianto@fp.unila.ac.id

\begin{abstract}
The aim of this study was to estimate the value of repeatability of weaning weight and Most Probable Producing Ability (MPPA) value of Saburai Doe in village breeding center (VBC), located in Tanggamus Regency. This research was conducted in Sumberejo and Gisting districts in January to May 2018. Data collected in this study included the recording data of kids' birth, birth weight, weaning age, weaning weight, offspring sex from 122 doe who have given birth twice from 2015 to 2017 . The study was carried out by using survey method to know weaning weight, estimated repeatability values, and MPPA values of Saburai doe in Sumberejo and Gisting district. Results of this research shows that the average corrected weaning weight of Saburai Doe in Sumberejo and Gisting district were $16.59 \pm 3.45$ and $16.93 \pm 2.90$, with the repeatability value were 0.76 and 0.59 (high category), respectively. The result also shows that the average value of MPPA of Saburai Doe were $16.59 \pm 2.98$ and $16.93 \pm 2.15$, respectively. There were 10 doe with the highest MPPA value consisting of 5 does from Sumberejo district K2 22.07, Y3 21.95, Y4 21.80, K1 21.39, AD3 21.38 and 5 does from Gisting District D3 22.03, B1 21.09, D4 20.98, A1 20.83, D5 20.74. It is suggested to select Saburai Doe with the best MPPA to improve productivity of Saburai Doe for the next generation.
\end{abstract}

Keywords: MPPA value, Repeatability, Saburai goat, Weaning weight

\section{Introduction}

Among other locations outside Java Island, Lampung is a province with highest population number of goat, reaching 1,297,872 (Badan Pusat Statistik, 2017). One of goat breeds that currently under development in Lampung is Saburai breed which is a meat-type crossbreed goat between Boer buck and Peranakan Etawah (PE) doe. Furthermore, Saburai breed has been established as a local genetic resource from Lampung Province according to Keputusan Menteri Pertanian Republik Indonesia (Decree of Ministry of Agriculture, Republic of Indonesia) Number 359/Kpts/PK.040/6/2015.

Saburai goat is known as dual purpose animal, producing both milk and meat. Apart from the fact that Saburai goat is easy to rear, high reproduction performance, high adaptability, and high productivity are other positive values of Saburai goat.

Several means to improve production performance of Saburai goat are continuously being carried out to accelerate the development of Saburai goat as one of local genetic resources. One of ways to achieve that goal is by selecting Saburai goat based on the weaning weight.
Weaning weight is one of traits that has economical value and positive correlation with one-year weight (Adhianto et al., 2016; Guiturres et al., 2007).

Animal selection to improve weaning weight of Saburai goat can be performed according to the Most Probable Producing Ability (MPPA) of weaning weight that represents the production ability of the doe. The value is quantified based on the weaning weight of their offsprings, estimated according to their ranks in the population group. Data required in estimation of MPPA value of weaning weight are repeatability value, number of paritas, mean of weaning weight per paritas, and mean of weaning weight of doe population (Warwick et al., 1990; Hardjosubroto, 1994).

The value of MPPA of weaning weight can be used to select doe that expected to have high genetic value to produce offsprings whose high weaning weight. Thus, doe whose high MPPA value can be kept in the population to enhance the weaning weight traits of their future generations. Hence, this study was performed to estimate the repeatability and MPPA value of weaning weight of Saburai Doe. 


\section{Materials and Methods}

\section{Materials}

Materials on this study included recording data of 65 Saburai doe in Sumberejo sub-district and 60 Saburai doe in Gisting sub-districts. The data comprised the age of doe when giving birth, birth weight of the offspring, weaning age, weaning weight, and offspring sex born between 2015 and 2017; and questionnaire for farmers.

\section{Methods}

The study was carried out by using survey method. The primary data were collected from questionnaire completed by farmers, while secondary data used in this study was recording data of goat owned by farmers. Sample were collected by using purposive sampling technique. Variables recorded in this study include the age of doe when giving birth, birth weight of the offspring, offspring sex, type of partus, weaning age, and weaning weight.

Calculated variables include corrected weaning weight, repeatability, and MPPA value. Corrected weaning weight was estimated according to this following formula (Hardjosubroto, 1994).

$$
\mathrm{BST}=\left(\mathrm{BL}+\left\langle\frac{\mathrm{BS}-\mathrm{BL}}{\mathrm{US}} \mathrm{x} 120\right\rangle(\mathrm{FKJK})(\mathrm{FKTL})(\mathrm{FKUI})\right.
$$

Notes:

BST: corrected weaning weight

$\begin{array}{ll}\text { BL } & : \text { birth weight }(\mathrm{kg}) \\ \text { BS } & : \text { weaning weight }(\mathrm{kg}) \\ \text { US } & : \text { weaning age (days) } \\ \text { FKJK } & : \text { sex correction factor } \\ \text { FKTL } & : \text { partus type correction factor } \\ \text { FKUI } & : \text { age of doe correction factor }\end{array}$

Estimation of repeatability value on this study was performed by using interclass correlation method. According to Warwick et al. (1990), the estimation of repeatability value using interclass correlation method follows this following formula:

$\mathrm{r}=\frac{\sum \mathrm{xy}}{\sqrt{\sum \mathrm{x}^{2} \sum \mathrm{y}^{2}}}=\frac{\sum \mathrm{XY}-\frac{\sum \mathrm{X} \sum \mathrm{Y}}{\mathrm{n}}}{\sqrt{\left(\sum \mathrm{X}^{2}-\frac{(\Sigma \mathrm{X})^{2}}{\mathrm{n}}\right)\left(\sum \mathrm{Y}^{2}-\frac{(\Sigma \mathrm{Y})^{2}}{\mathrm{n}}\right)}}$

Notes:

$r=$ repeatability value

$\mathrm{x}=$ weaning weight of kid from the first birth

$y=$ weaning weight of kid from the second birth

$\mathrm{n}=$ number of doe

The value of MMPA of weaning weight was calculated by using formula according to Hardjosubroto (1994) as follows:

Notes:

$$
M P P A=\frac{n r}{1+(n-1) r}(\bar{P}-\overline{\bar{P}})+\overline{\bar{P}}
$$

MPPA = most probable producing ability $(\mathrm{kg})$

$\mathrm{N} \quad=$ birth frequency

$$
\begin{aligned}
\mathrm{r} & =\text { repeatability of weaning weight } \\
\overline{\mathrm{P}} & =\text { mean of weaning weight per doe }(\mathrm{kg}) \\
\overline{\overline{\mathrm{P}}} & =\text { mean of weaning weight in population } \\
& \text { group }(\mathrm{kg}) .
\end{aligned}
$$

\section{Results and Discussion}

\section{Overview: Sumberejo Sub-District and Gisting Sub-District in Tanggamus Regency}

Sumberejo sub-district and Gisting subdistrict are situation in high-altitude location, with environment temperature ranging from $20.8^{\circ} \mathrm{C}$ to $22.5^{\circ} \mathrm{C}$. Agriculture sector that provides food commodity, plantation, forestry, and animal products serve as the main income source in those two sub-districts. The high fertility of soil in Tanggamus Regency serves as supporting factor for animal production sector as it enables either grass or legume to grow well. That condition drives local community in Tanggamus Regency to develop goat production.

Saburai goat in the Sumberejo and Gisting are housed in individual high-stage facility. The gable roof are built by using asbestos. Woven bamboo make up the floor, with interwoven holes - allowing the feces to fall down to be collected under the facility or cage.

Saburai goat in Sumberejo and Gisting were fed with forages, that included grass, legume (calliandra, gliricidia, and indigofera), and other leafy greens collected around the farmers' house (such as: cassava leaves, mahogany leaves, and sengon leaves). Feeding were performed twice a day (morning and evening). Meanwhile, water is supplied once a day, delivered in a basin.

Simple health management for Saburai goat was carried out by administering worm medicine and sanitation approach in the animal facility. The worm medicine is given to the Saburai goat once in 3 to 6 months to either treat or prevent worm infection.

\section{Corrected weaning weight of Saburai goat}

Result on this study indicates that average of corrected weaning weight (BSt) of Saburai goat on first partus in Sumberejo and Gisting were $17.74 \pm 4.08 \mathrm{~kg}$ and $17.74 \pm 3.50 \mathrm{~kg}$ respectively. Meanwhile, on the second partus the average of corrected weaning weight of Saburai goat in those location wree $15.45 \pm 3.28 \mathrm{~kg}$ and $16.12 \pm 3.00 \mathrm{~kg}$ (see Table 1).

The variation of BSt value in those surveyed location were caused by the genetic variation among Saburai goat as they are originated from different locations. Saburai goat in Gisting sub-districts are obtained by breeding strategy between buck and doe of Saburai available in Gisting. Meanwhile, in Sumberejo, the Saburai goat are produced by breeding strategy between Boer buck and Boerawa doe (a crossbreeding result from Boer buck and PE doe). Offspring obtained from those breeding approaches are developed in each location. 
Table 1. Corrected weaning weight of Saburai kid from first and second partus in Sumberejo sub-district and Gisting sub-district

\begin{tabular}{|c|c|c|c|c|}
\hline \multirow[b]{2}{*}{ Description } & \multicolumn{2}{|c|}{ Sumberejo } & \multicolumn{2}{|c|}{ Gisting } \\
\hline & $\begin{array}{l}\text { Paritas 1 } \\
\text { (partus 1) }\end{array}$ & $\begin{array}{l}\text { Paritas 2 } \\
\text { (partus 2) }\end{array}$ & $\begin{array}{l}\text { Paritas } 1 \\
\text { (partus 1) }\end{array}$ & $\begin{array}{l}\text { Paritas 2 } \\
\text { (partus 2) }\end{array}$ \\
\hline The highest corrected weaning weight $(\mathrm{kg})$ & 25.92 & 21.61 & 27.10 & 23.90 \\
\hline The lowest corrected weaning weight $(\mathrm{kg})$ & 9.27 & 6.79 & 12,67 & 11.64 \\
\hline Average of weaning weight $(\mathrm{kg})$ & $17.74 \pm 4.08$ & $15.45 \pm 3.28$ & $17.74 \pm 3.50$ & $16.12 \pm 3.00$ \\
\hline Average of birth weight $(\mathrm{kg})$ & $3.18 \pm 0.45$ & $3.04 \pm 0.39$ & $3.26 \pm 0.52$ & $3.17 \pm 0.49$ \\
\hline Age of doe at partus (months) & $17.35 \pm 1.69$ & $28.05 \pm 1.81$ & $17.60 \pm 1.72$ & $26.73 \pm 1.84$ \\
\hline Weaning age (days) & $112.26 \pm 14.31$ & $112.26 \pm 14.31$ & $93.50 \pm 9.71$ & $94.00 \pm 10.58$ \\
\hline Single birth (head) & 23 & 15 & 30 & 35 \\
\hline Twin birth (head) & 39 & 47 & 30 & 25 \\
\hline Total number of male kid (head) & 37 & 52 & 40 & 37 \\
\hline Total number of female kid (head) & 64 & 57 & 50 & 48 \\
\hline
\end{tabular}

The origin of PE goat used to produce Saburai goat in those sub-districts are also different. It resulted in the genetic variation that determines the variation of weaning weight performance of Saburai goat in the two locations. It aligns with Hardjosubroto (1994) and Devendra and Burns (1994), animal population that originated from different location have high genetic variation.

Average of BSt of Saburai goat on this study is smaller than what have been reported from other study, such as Suhartanti (2017) in Sumberejo sub-district $(22.13 \pm 4.39 \mathrm{~kg})$ and in Gisting $(20.84 \pm 3.68 \mathrm{~kg})$. The difference is a result of different goats observed on the two studies. On this study, the observation was carried out for goat that born between 2015 and 2017, while Suhartanti (2017) performed the study between 2015 and 2016.

\section{Repeatability value of weaning weight of Saburai Goat}

Repeatability value of Saburai goat in Sumberejo were recorded as 0.76 , indicating that $76 \%$ of the weaning weight differences were caused by genetic variation and permanent environment, while the rest of $24 \%$ due to the temporary environment factors. Repeatability value of weaning weight of Saburai goat in Gisting sub-district were recorded as 0.59 , demonstrating that as many as $56 \%$ of the weaning weight variation were produced by the genetic variation and permanent environment factor, while the rest of $41 \%$ were caused by temporary environment factors.

The repeatability value of Saburai goat on this study can be considered as high value. Noor (2010) reported that repeatability value greater than 0.4 is classified as high value. Warwick et al. (1990) and Sulastri (2014) stated that repeatability value of high performance shows the ability of the animals to produce offspring with low variation or the performance among offspring are expected to be highly homogenous on the first and next partus. Repeatability is the limit used in heritability estimation (Odubote and Akinokun, 1992), thus, high repeatability value on certain trait indicates the high repeatability on that trait.

The varied repeatability value of weaning weight in the two locations studied on this study were caused by genetic variation of weaning weight of Saburai goat in Gisting and Sumberejo due to the fact that the goat were originated from different locations. Sulastri (2014) stated that genetic and permanent environment factors affects the performance of goat during gestation and after partus, while temporary environment factors only affects the offspring performance only after partus. Temporary environment factors include feed and other condition that directly affecting phenotypically of the doe (Das et al., 1994).

Repeatability value of weaning weight of Saburai goat on this study $(0.76$ and 0.6$)$ differ from Beyleto et al. (2010) on Boerawa goat in Gisting sub-district, Tanggamus regency. Repeatability value of Boerawas were estimated by using interclass correlation method, and reported as many as $0.32 \pm 0.08$. Pirdania et al. (2014) reported another repeatability value of weaning weight of Boerawa goat as many as 0.335 . The difference of repeatability value on this study with either Beyleto et al. (2010) or Pirdania et al. (2014) were caused by differences of animals and breed observed on those study (Pattie and James, 1985). On this study, Saburai goat were observed, while Beyleto et al. (2010) and Pirdania et al. (2014) studied on Boerawa goat.

\section{MPPA value of Saburai Doe}

Production performance of Saburai goat can be achieved by selection strategy to the doe that able to produce high weaning weight of their offspring. The weaning weight represents the direct effect of growth gene inherited by parents and mother ability value of the doe (Chantalakhana, 1968).

This study shows that the average of MMPA value of weaning weight of Saburai goat in Sumberejo sub-district were $16.59 \pm 2.98 \mathrm{~kg}$, while in Gisting sub-district were reported as $16.93 \pm 2.15$ $\mathrm{kg}$ (see Table. 2). Coefficient of MPPA value variation of Saburai goat in Sumberejo $(17.97 \%)$ is greater that in Gisting (12.69\%). Warwick et al. (1990) and Hardjosubroto (1994) reported that the greater number of buck and doe in a population can increase heterozygosity or genetic variation and prevent homozygosity to increase. Repeatability value and production performance on each partus affects the MPPA value of doe (Sulastri, 2014).

The MPPA value of weaning weight on this study is smaller than what has been reported by 
Table 2. Most Probable Producing Ability (MMPA) value of weaning weight of Doe of Saburai Goat

\begin{tabular}{lcc}
\hline \hline Descriptions & Sumberejo & Gisting \\
\hline The highest MPPA $(\mathrm{kg})$ & 22.07 & 22.03 \\
The lowest MPPA $(\mathrm{kg})$ & 9.81 & 13.38 \\
The average value of MPPA $(\mathrm{kg})$ & 16.59 & 16.93 \\
Standard deviation & 2.98 & 2.15 \\
Total number of sample (head) & 62 & 60 \\
Total number of sample above the average (head) & 27 & 24 \\
Coefficient of diversity (\%) & 17.97 & 12.69 \\
\hline
\end{tabular}

Sulastri (2010), in which the average of MPPA value of weaning weight of Saburai goat in Sumberejo, Tanggamus Regency on Sulastri's study was reported as many as $22.57 \mathrm{~kg}$. The variation of MPPA value is presumably caused by the higher weaning weight on Sulastri (2010) study, which was $22.12 \pm 1.93 \mathrm{~kg}$. It is aligned with what Harjosubroto (1994) stated before that MPPA value is altered by the performance repeatability value, partus frequency, and average of performance in the population.

The calculation MPPA value in Sumberejo that was carried out on 62 Saburai goat, as many as 27 Saburai doe (43.55\%) had greater MPPA value than the average, while the rest of 35 doe (56.65) had smaller MPPA value than the average value. Among 60 Saburai doe in Gisting subdistrict, 24 doe (40\%) had greater MPPA value than the average value and 36 doe $(60 \%)$ had smaller MPPA value that the average. There were the highest 10 MPPA value that 5 of them observed in Sumberejo (K2 22,07, Y3 21,95, Y4 21,80, K1 21,39, AD3 21,38), and the other 5 seen in Gisting sub-district (D3 22,03, B1 21,09, D4 20,98, A1 20,83, D5 20,74).

\section{Conclusions}

According to the study, the repeatability value of weaning weight of Saburai goat in Sumberejo sub-district and Gisting sub-district can be classified in the high category.

\section{Acknowledgment}

Authors on this study are expressing gratitude to Kementerian Riset Teknologi dan Pendidikan Tinggi (Ministry of Research, Technology, and Higher Education) for providing research grant to fund this study through Penelitian Terapan Unggulan Perguruan Tinggi (PTUPT) scheme.

\section{References}

Adhianto, K., M. D. I. Hamdani, Sulastri, and I. Listiana. 2016. Performan produksi kambing Saburai jantan pada dua wilayah sumber bibit di Kabupaten Tanggamus. Sains Peternakan14: 22-29.

Badan Pusat Statistik. 2017. Populasi Kambing Menurut Provinsi Tahun 2009 -2016. https//www.bps.go.id. diakses pada 15 November 2017.
Beyleto, V. Y., Sumadi, and T. Hartatik. 2010. Estimasi parameter genetik sifat pertumbuhan Kambing Boerawa di Kabupaten Tanggamus Provinsi Lampung. Buletin Peternakan 34:138-144.

Chantalakhana, C. 1968. Cow weights and other factors affecting calf weaning weight. Dissertations. lowa State University Ames, lowa.

Das, S. M., J. E. O. Rege, and M. Shibre. 1994. Phenotypic and genetic parameters of growth traits of Blended goats at Malya, Tanzania. Small ruminant Research and Development in Africa; proceedings of the $3^{\text {rd }}$ biennial conference of the African Small Ruminant Research Network UICC Kampala, Uganda, 5 - 9 December pp. 6368.

Devendra, C. and M. Burns. 1994. Produksi Kambing di Daerah Tropis. Penerbit ITB, Bandung.

Guiturres, J. P., F. Goyache, I. Fernández, I. Alvarez, and L. J. Royo. 2007. Genetic relationship among calving ease, calving interval, birth weight, and weaning weight in the asturiana de los valles beef cattle breed. J. Anim. Sci. 85: 67-75.

Hardjosubroto, W. 1994. Aplikasi Pemuliabiakan Ternak di Lapangan. PT Grasindo, Jakarta.

Noor, R. R. 2010. Genetika Ternak. Penebar Swadaya, Jakarta.

Odubote, I. K. and J. O. Akinokun. 1992. Estimates of genetic parameters for economic traits in west african dwarf goat. AJOL. 19: 114-119.

Pattie, W. A. and J. W. James. 1985. Principle of Applied Animal Breeding. Department of Animal Breeding. University of Queensland, Queensland.

Pirdania, I., I. Harris, and M. D. I. Hamdani. 2014. Seleksi induk kambing Boerawa berdasarkan nilai pemuliaan bobot sapih di Kecamatan Gisting, Kabupaten Tanggamus. Jurnal Ilmiah Peternakan Terpadu 2: 25-28.

Suhartanti, T. Y. 2017. Nilai indeks produktivitas induk kambing Saburai di Kecamatan Sumberejo dan Kecamatan Gisting Kabupaten Tanggamus. Skripsi Fakultas Pertanian, Universitas Lampung.

Sulastri. 2010. Genetic potency of weaning weight of Boerawa F1, backcross 1 and backcross 2 does at Breeding Village Centre, Tanggamus Regency, Lampung Province. Proceeding of the $5^{\text {th }}$ International Seminar 
of Tropical Animal Production. Pp. 556560.

Sulastri. 2014. Karakteristik Genetik Bangsa Bangsa Kambing di Provinsi Lampung. Disertasi. Program Pascasarjana Fakultas
Peternakan. Universitas Gajah Mada, Yogyakarta.

Warwick, E.J., J. M. Astuti, and W. Hardosubroto. 1990. Pemuliaan Ternak. Gajah Mada University Press, Yogyakarta. 